\title{
Outcomes of a Dispersive Ophthalmic Viscosurgical Device
}

\author{
Banu Acar, ${ }^{1}$ 이 Isil Merve Torun, ${ }^{2}$ (으 Suphi Acar ${ }^{3}$
}

1Department of Ophthalmology, Biruni University Faculty of Medicine, Istanbul, Turkey

2Department of Ophthalmology, Sultan Abdulhamid Han Training and Research Hospital, Istanbul, Turkey

${ }^{3}$ Department of Ophthalmology, Bati Goz Hospital, Istanbul, Turkey

\begin{abstract}
Objectives: The aim of this study was to evaluate clinical outcomes related to the protection of corneal endothelial cells and the safety of the Bio-Hyalur CS (Biotech Healthcare Group, Luzern, Switzerland) ophthalmic viscosurgical device (OVD) in routine cataract surgery.

Methods: Patients who had undergone cataract surgery using Bio-Hyalur CS as an OVD and who had at least 3 months of follow-up data were included in the study. Endothelial cell density (ECD) and morphology (hexagonality, area, and coefficient of variation in cell size) as well as intraocular pressure were evaluated during 3 months of follow-up. Intraoperative and postoperative complications were recorded.

Results: Sixty eyes of 44 patients were included in the study. The mean preoperative ECD was $2383.5 \pm 288.67$ cells/ $\mathrm{mm}^{2}$. The mean postoperative ECD was $2186.0 \pm 359.65 \mathrm{cells} / \mathrm{mm}^{2}$ and $2149.7 \pm 354.49 \mathrm{cells} / \mathrm{mm}^{2}$ at I- and 3-month visits, respectively. The mean coefficient of variation in cell size was $29.1 \pm 5.04 \%$ and $30.9 \pm 5.79 \%$ at preoperative and postoperative 3-month visits, respectively. The mean cell area was $426.1 \pm 52.59 \mu \mathrm{m}^{2}$ and $476.6 \pm 122.26 \mu \mathrm{m}^{2}$ at preoperative and postoperative 3-month visits, respectively. No adverse events were reported during the study period.

Conclusion: Bio-Hyalur CS provided good endothelial protection and has a favorable safety profile. However, comparative studies with other OVDs are necessary.

Keywords: Cataract surgery, corneal endothelial cells, dispersive, ophthalmic viscoelastic device.
\end{abstract}

\section{Introduction}

Ophthalmic viscosurgical devices (OVDs) play a very important role in modern cataract surgery. They provide a workspace for the surgeon and protect corneal endothelial cells from possible trauma from mechanical effects of surgical instruments, lens implantation maneuvers, and nuclear lens material fragments, as well as the ultrasonic energy applied during phacoemulsification $(I, 2)$. Potential complications of the use of OVDs include postoperative inflammation and an increase in intraocular pressure (IOP) in the immediate postoperative period (3).

Different OVD properties are required to adequately fulfill the needs of different surgical steps. The ideal OVD should be non-toxic, create and retain a deep anterior chamber, and protect the corneal endothelium. In addition, it should be easy to inject and easy to remove. There are currently numerous OVDs on the market with different rheologically active polymeric substances, concentrations, and chain lengths, which results in different physical and chemical properties (I). These OVDs are currently classified depending on zero-shear viscosity and dispersion-cohesion properties $(I, 4)$.

Bio-Hyalur CS (Biotech Healthcare Group, Luzern, Switzerland) is a new, medium-viscosity, dispersive OVD, according to the classification proposed by Arshinoff and Jafari (I) (Table I). This is a retrospective evaluation of the performance and safety of Bio-Hyalur CS in cataract surgery. 
Table I. Specifications of Bio-Hyalur CS

$\begin{array}{ll}\text { Raw material } & \begin{array}{l}\text { Sodium hyaluronate content }(2.0 \%) \\ \text { Sodium chondroitin sulfate content }(2.0 \%)\end{array} \\ \text { Viscosity } & \text { at I shear rate }-40.000 \pm 5.000 \mathrm{mPas} \\ \mathrm{pH} & 6.8 \text { to } 7.6 \\ \text { Osmolarity } & 340-400 \mathrm{mOsm} / \mathrm{kg} \\ \text { Source } & \text { Bacterial fermentation } \\ \text { Molecular weight } & 4.7 \text { to } 4.9 \text { million Daltons } \\ \text { Elasticity } & 40.000 \pm 15.000 \mathrm{mPas} \\ & \left.\text { (at shear rate of I sec-I, } 25^{\circ} \mathrm{C}\right)\end{array}$

Bio-Hyalur; Biotech Healthcare Group, Luzern, Switzerland.

\section{Methods}

This was a retrospective, observational study conducted to evaluate the clinical outcomes related to the protection of corneal endothelial cells and complications in patients undergoing routine cataract surgery. The study was performed in accordance with the Declaration of Helsinki. The study protocol was approved by the Umraniye Training and Research Hospital Clinical Trials Ethical Committee in Istanbul, Turkey, I4.03.2017 no: B.10.I.THK.4.34.H.GP.0.0I/25.

Medical records of patients who underwent cataract surgery using Bio-Hyalur CS were retrospectively reviewed. Patients who met the following criteria were included in the study: patients aged $\geq 45$ years, Grade I, II, or III unilateral/bilateral cataract, healthy eyes excluding the formation of cataract, compliance with all of the regular followup examinations per the routine schedule. Patients who met any of the following criteria were excluded from the study: black, brunescent, traumatic, or subluxated cataract; corneal endothelial disease; pre-operative endothelial cell density $(E C D)<1500$ cells $/ \mathrm{mm}^{2}$ in the operative eye; glaucoma; pseudoexfoliation syndrome with glaucoma; iris atrophy; proliferative diabetic retinopathy; history of chronic or recurrent inflammatory eye disease (e.g., iritis, scleritis, uveitis, iridocyclitis, rubeosis iridis); or previous intraocular or corneal surgery. All of the patients were assessed at a clinical follow-up I day, I week, I month, and 3 months after the surgery. Endothelial cell density, cell area, coefficient of variation in cell size, and cell hexagonality were measured preoperatively and at postoperative I- and 3-month visits with a CEM-530 specular microscope (Nidek Co, Ltd, Gamagori, Japan). Corneal thickness was measured preoperatively and at postoperative I- and 3-month visits using the Sirius corneal topography system (Costruzioni Strumenti Oftalmici, Firenze, Italy). IOP was measured with an applanation tonometer at every visit. The effective phacoemulsi- fication time and average phacoemulsification power were also recorded from patient files.

\section{Statistical Analysis}

Statistical analysis was performed using SAS Version 9.4 (SAS Institute Inc., Cary, NC, USA). The mean, SD, and frequency were used in the statistical analysis. The assumption of normality was assessed using the Shapiro-Wilk test. Parametric and non-parametric data were analyzed using a paired samples t-test and the Wilcoxon signed-rank test, respectively. A $p$-value $<0.05$ was considered statistically significant for all tests.

\section{Results}

Sixty eyes of 44 patients were included in the study. Table 2 is a summary of baseline demographic characteristics. The number of eyes with a Grade I, Grade II, and Grade III cataract was 8 (13.33\%), 30 (50.00\%), and 22 (36.67\%), respectively. The mean effective phacoemulsification time and the average phacoemulsification power was $46.0 \pm 12.78$ seconds and $30.7 \pm 8.21 \mu \mathrm{m}$, respectively.

Preoperative and postoperative ECD and morphological parameters are listed in Table 3. There was a statistically significant decrease in the mean ECD at the month-I visit when compared with the preoperative visit. However, the mean ECD was not significantly different between the postoperative $\mathrm{I}$ - and 3-month visits. The mean percent change in the endothelial cell count was $8.6 \pm 7.37 \%$ and $10.1 \pm 7.23 \%$ at postoperative month I and month 3 , respectively. There was a statistically significant increase in the IOP at the firstday postoperative visit $(p<0.000$ I) (Fig. I). However, the IOP was $<25 \mathrm{mmHg}$ in all of the patients on the first day after surgery. At subsequent follow-up visits, the IOP was <2I $\mathrm{mmHg}$ (without any antiglaucoma medication). The cornea was clear for all 60 (100\%) eyes at the last follow-up visit. No anterior chamber reaction, flare, or cells were observed in any of the patients I day after surgery. No complications were recorded in the patient files.

Table 2. Summary of patient baseline demographic characteristics

Variables

$\begin{array}{lc}\text { Age (years) } & \\ \text { Mean } \pm \text { SD } & 64.6 \pm 9.29 \\ \text { Median } & 63 \\ \text { Range } & 46-85 \\ \text { Gender, } n(\%) & \\ \text { Male } & 18(41) \\ \text { Female } & 26(59)\end{array}$


Table 3. Corneal parameters during follow-up

\begin{tabular}{|c|c|c|c|c|c|}
\hline & $\begin{array}{c}\text { Preoperative } \\
\text { Mean士SD }\end{array}$ & $\begin{array}{c}\text { Month I } \\
\text { Mean士SD }\end{array}$ & $\begin{array}{c}\text { Month } 3 \\
\text { Mean士SD }\end{array}$ & $\mathbf{p}^{*}$ & $\mathbf{p}^{* *}$ \\
\hline Endothelial cell density (cells $/ \mathrm{mm}^{2}$ ) & $2383.5 \pm 288.67$ & $2186.0 \pm 359.65$ & $2149.7 \pm 354.49$ & $<0.0001$ & 0.1852 \\
\hline Coefficient of variation (\%) & $29.1 \pm 5.04$ & $31.6 \pm 4.79$ & $30.9 \pm 5.79$ & $<0.0001$ & 0.1017 \\
\hline Hexagonality (\%) & $69.0 \pm 4.87$ & $64.0 \pm 5.12$ & $65.8 \pm 5.74$ & $<0.0001$ & 0.1236 \\
\hline Cell area $\left(\mu \mathrm{m}^{2}\right)$ & $426.1 \pm 52.59$ & $470.7 \pm|17.4|$ & $476.6 \pm 122.26$ & 0.1167 & 0.1019 \\
\hline
\end{tabular}

*: Preoperative visit versus I-month visit; **: I-month visit versus 3-month visit.

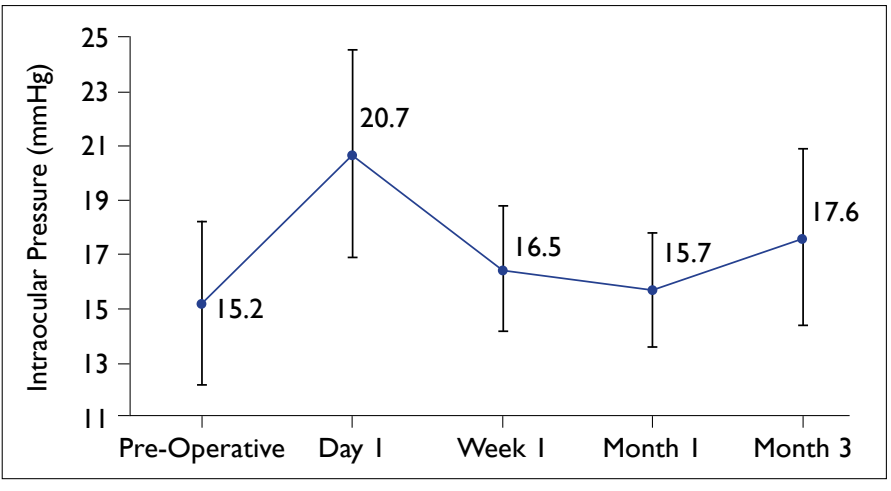

Figure I. Change in central macular thickness; I) Baseline central macular thickness (CMT); 2) CMT at the second month of treatment; 3) CMT at the fourth month of treatment; 4) CMT at the sixth month of treatment; * statistically significant.

\section{Discussion}

This pilot study was an evaluation of the surgical results of a new OVD to assess the safety and effectiveness. The main functions of OVDs are to maintain the anterior chamber and protect the corneal endothelium. However, it is well known that endothelial cell loss occurs during cataract surgery despite the protective properties of OVDs and may continue in the early postoperative phase $(7,12)$. Postoperative changes in the corneal ECD are a reliable means of analyzing the endothelium-protecting efficacy of an OVD. Bio-Hyalur CS is a medium-viscosity, dispersive OVD. Rheological properties indicate that a dispersive OVD, with its propensity to coat and protect intraocular tissues, might be better than a cohesive OVD for endothelial protection (5). However, this issue is controversial (6).

In this study, we found that there was a statistically significant decrease in the mean ECD at the month-I visit. The mean loss in ECD was $8.6 \pm 7.37 \%$ I month after surgery when compared with the preoperative ECD. However, the mean ECD was not significantly different between the postoperative I- and 3-month visits. Although there are several studies reporting ECD loss with different OVDs, it is difficult to draw a conclusion by comparing different studies because other parameters that have an impact on ECD loss were not controlled for. Surgeries are performed by different surgeons and in addition, the preoperative patient characteristics, phacoemulsification parameters, and cumulative dissipated phacoemulsification energy may differ considerably in different studies.

In our study, the mean ECD was $2383.5 \pm 288.67$ cells/ $\mathrm{mm}^{2}$ and $2186.0 \pm 359.65$ cells $/ \mathrm{mm}^{2}$ preoperatively and at the I-month visit, respectively. Das et al. (7) evaluated the relative effects of high and low fluidic parameters on ECD in a prospective, randomized clinical trial. They used a dispersive OVD composed of $3.0 \%$ sodium hyaluronate and $4.0 \%$ chondroitin sulfate (Viscoat; Alcon Inc., Fort Worth, TX, USA). The rheological properties of Viscoat are similar to those of Bio-Hyalur CS (Table I). The study included 65 patients each in high and low flow groups. The preoperative ECD was $2550 \pm 343$ cells $/ \mathrm{mm}^{2}$ and $2489 \pm 234$ cells $/ \mathrm{mm}^{2}$, respectively, in the high and low flow groups. Similar to our study, they found that the change in ECD in the 2 groups at 6 weeks was $284 \pm 384$ cells $/ \mathrm{mm}^{2}$ and $243 \pm 252$ cells $/ \mathrm{mm}^{2}$, respectively.

Papaconstantinou et al. (8) assessed and compared the safety and the efficacy of VisThesia (Carl Zeiss Meditec AG, Jena, Germany) and Viscoat in a prospective randomized clinical trial. The mean endothelial cell count was $2322.3 \pm 161$.I cells $/ \mathrm{mm}^{2}$ in the Viscoat group and $2304.8 \pm 142.8$ cells $/ \mathrm{mm}^{2}$ in the VisThesia group. At 15 days after cataract surgery, the mean endothelial cell decrease was 212 cells $/ \mathrm{mm}^{2}(9.1 \%)$ in the Viscoat group and 272 cells $/ \mathrm{mm}^{2}(\mathrm{II} .8 \%)$ in the VisThesia group. Holzer et al. (6) compared 5 OVDs commonly used during phacoemulsification in terms of ECD loss in a prospective randomized study. They did not confirm that dispersive OVDs protect the endothelium better than cohesive OVDs. In fact, the lowest mean cell loss $(6.2 \pm 6.5 \%)$ was in the Healon 5 (Abbott Medical Optics, Inc., Santa Ana, CA, USA) group, a cohesive agent, and the greatest cell loss was seen in the OcuCoat (Bausch \& Lomb, Rochester, NY, USA) group (16.7 $\pm 10.8 \%)$. OcuCoat contains hydrox- 
ypropyl methylcellulose $(2.0 \%)$ and has dispersive characteristics. Viscoat, also a dispersive agent, yielded a cell loss of $15.4 \% \pm 9.1 \%$. In light of the above studies, our results indicate a favorable endothelial safety profile for Bio-Hyalur CS. Revealing the relative protective effect of Bio-Hyalur CS compared with other OVDs is beyond the scope of this pilot study and will require prospective controlled studies.

We found a statistically significant increase in the mean IOP at I day after surgery. However, IOP was $<25 \mathrm{mmHg}$ in all patients. The IOP was $<21 \mathrm{mmHg}$ (without any antiglaucoma medication) in the follow-up visits. In a European multicenter study comparing the clinical performance and safety of 2 OVDs, the incidence of IOP spike $\geq 24 \mathrm{mmHg}$ was $3.7 \%$ and $5.4 \%$ in Twinvisc (Carl Zeiss Meditec AG, Jena, Germany) and Duovisc (Alcon Inc., Fort Worth, TX) groups $(p=0.748)$, respectively (9). The mechanism of postoperative IOP increase is not yet fully understood. However, it is assumed that remaining viscoelastic agent mechanically obstructs the trabecular outflow pathway and decreases the outflow facility (10). Thus, a thorough removal of the OVD at the conclusion of surgery may decrease the incidence of increased IOP. In this study, the OVD was removed with great care from the anterior chamber. The turnover of injected sodium hyaluronate depends on the viscosity of the injected solution, and less viscous sodium hyaluronate results in a shorter prolonged elevation in IOP than high-viscosity preparations of sodium hyaluronate. However, high- viscosity agents are easier to completely remove from the anterior chamber (10). Accordingly, surgeon experience and the rheological properties of the OVD both have an effect on the postoperative increase in IOP $(\mathrm{II}-13)$. Also, the presence of glaucoma and ocular hypertension, high preoperative $I O P$, and long axial length are associated with increased early postoperative IOP (II). Our findings were consistent with those reported in the literature describing an early postoperative IOP elevation followed by a return to baseline values after approximately 24 hours $(6,9,13)$.

The major limitation of this study is its retrospective nature. No anterior chamber reaction, flare, or cells were observed in the anterior chamber in any of the patients at postoperative visits. However, due to the retrospective nature of the study, objective measures of anterior chamber inflammation or flare are missing. Thus, mild postoperative inflammation may have gone unnoticed.

\section{Conclusion}

In conclusion, we evaluated the clinical results of a new, medium-viscosity dispersive OVD. In this pilot study, we found that Bio-Hyalur CS created and maintained anterior chamber depth and provided good corneal endothelial protection. We encountered no serious complications.
Although we found Bio-Hyalur CS to be safe and effective for cataract surgery, prospective comparative studies with control groups are necessary to determine the relative advantages and disadvantages compared with other OVDs.

\section{Disclosures}

Ethics Committee Approval: The study protocol was approved by the Umraniye Training and Research Hospital Clinical Trials Ethical Committee in Istanbul, Turkey (14.03.2017 B.I0.I.THK.4.34.H.GP.0.0I/25).

Peer-review: Externally peer-reviewed.

Conflict of Interest: None declared.

Authorship Contributions: Involved in design and conduct of the study (BA, SA); preparation and review of the study (BA, IMT, $\mathrm{SA})$; data collection (IMT); and statistical analysis (BA, IMT).

\section{References}

I. Anger C, Lally JM. Acanthamoeba: A review of its potential to cause keratitis, current lens solution disinfection standards and methodologies and strategies to reduce patient risk. Eye Contact Lens 2008;34:247-53. [CrossRef]

2. Visvesvara GS. Free-living pathogenic amoeba. In: Lennette EH, Balows A, Hausler WJ Jr, editors. Manual of Clinical Microbiology. 3rd ed. Washington, DC: American Society of Microbiology 1980. p. 704-8.

3. Naginton J, Watson PG, Playfair TJ, McGill J, Jones BR, Steele AD. Amoebic infection of the eye. Lancet 1974;2:1537-40. [CrossRef]

4. Dart JK, Saw VP, Kilvington S. Acanthamoeba keratitis: Diagnosis and treatment update 2009. Am J Ophthalmol 2009;148:48799.e2. [CrossRef]

5. Radford CF, Bacon AS, Dart JK, Minassian DC. Risk factors for acanthamoeba keratitis in contact lens users: A case-control study. BMJ 1995;3 10:1567-70. [CrossRef]

6. Schaumberg DA, Snow KK, Dana MR. The epidemic of Acanthamoebakeratitis:Where do we stand? Cornea 1998;17:3-10.

7. Farhat B, Sutphin JE. Deep anterior lamellar keratoplasty for acanthamoeba keratitis complicating the use of Boston scleral lens. Eye Contact Lens 2014;40:e5-7. [CrossRef]

8. Yamazaki N, Kobayashi A, Yokogawa H, Ishibashi Y, Oikawa Y, Tokoro M, et al. In Vivo Imaging of Radial Keratoneuritis in $\mathrm{Pa}$ tients with Acanthamoeba keratitis by Anterior-Segment Optical Coherence Tomography. Ophthalmology 2014;121:2153-8.

9. Pullum KW, Whiting MA, Buckley RJ. Scleral contact lenses: The expanding role. Cornea. 2005;24:269-77. [CrossRef]

10. Segal O, Barkana Y, Hourovitz D, Behrman S, Kamun Y, Avni I, et al. Scleral contact lenses may help where other modalities fail. Cornea 2003;22:308-10. [CrossRef]

II. Romero-Rangel T, Stavrou P, Cotter J, Rosenthal P, Baltatzis S, Foster CS. Gas-permeable scleral contact lens therapy in ocular surface disease. Am J Ophthalmol 2000; 130:25-32. [CrossRef]

12. Fleiszig SM, Evans DJ. Pathogenesis of contact lens-associated 
microbial keratitis. Optom Vis Sci 2010;87:225-32.[CrossRef]

13. Zimmerman AB, Marks A. Microbial keratitis secondary to unintended poor compliance with scleral gas-permeable contact lenses. Eye Contact Lens 2014;40:e I-4. [CrossRef]

14. Jacobs DS, Rosenthal P. Boston scleral lens prosthetic device for treatment of severe dry eye in chronic graft-versus-host disease. Cornea 2007;26: I 195-9. [CrossRef]

I5. Rosenthal P, Cotter JM, Baum J. Treatment of persistent corneal epithelial defect with extended wear of a fluid-ventilated gas-permeable scleral contact lens. Am J Ophthalmol 2000; I30:33-4I.

16. Baran I, Bradley JA, Alipour F, Rosenthal P, Le HG, Jacobs DS. PROSE treatment of corneal ectasia. Cont Lens Anterior Eye 2012;35:222-7. [CrossRef]

17. Panjwani N. Pathogenesis of Acanthamoeba keratitis. Ocul Surf 2010;8:70-9. [CrossRef]

18. Cao Z, Saravanan C, Goldstein MH, Wu HK, Pasricha G, Sharma $S$, et al. Effect of human tears on Acanthamoeba- induced cytopathic effect. Arch Ophthalmol 2008; 126:348-52.
19. McClellan K, Howard K, Niederkorn JY, Alizadeh H. Effect of steroids on Acanthamoeba cysts and trophozoites. Invest Ophthalmol Vis Sci 2001;42:2885-93.

20. Por YM, Mehta JS, Chua JL, Koh TH, Khor WB, Fong AC, et al. Acanthamoeba keratitis associated with contact lens wear in Singapore. Am J Ophthalmol 2009; I48:7-12.e2. [CrossRef]

21. Sunada A, Kimura K, Nishi I, Toyokawa M, Ueda A, Sakata T, et al. In Vitro Evaluations of Topical Agents to Treat Acanthamoeba Keratitis. Ophthalmology 20|4;|21:2059-65. [CrossRef]

22. Cabello-Vílchez AM, Martín-Navarro CM, López-Arencibia A, Reyes-Batlle M, Sifaoui I, Valladares B, et all. Voriconazole as a first-line treatment against potentially pathogenic Acanthamoeba strains from Peru. Parasitol Res 2014;। I3:755-9. [CrossRef]

23. lovieno A, Miller D, Ledee DR, Alfonso EC. Cysticidal activity of antifungals against different genotypes of Acanthamoeba Antimicrob Agents Chemother. Antimicrob Agents Chemother 20|4;58:5626-8. [CrossRef] 